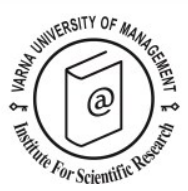

\title{
An essay on redefining tourism. An epistemological approach and town and country planning for tourism
}

\author{
Catherine Sicart ${ }^{1}$ \\ Received: 11/04/2016
}

\begin{abstract}
1 Tourism Management Department, Institute of Business Administration, Perpignan Via Domitia University, France, phone: (00 33) 6521993 21, e-mail: csicart@univ-perp.fr
\end{abstract}

Supervisors: Nicolas Peypoch

Institution awarding the Ph. D. Degree: Perpignan Via Domitia University.

Date of defence: 25/11/2015

(C) 2016 Varna University of Management. All rights reserved

Citation: Sicart C. (2016) An essay on redefining tourism. An epistemological approach and town and country planning for tourism. Doctoral Dissertation Summary. European Journal of Tourism Research 14, pp. 123-126

\section{Goal and objectives of the dissertation}

The doctoral dissertation aims to identify the origins of tourism in order to shed light on its present state and redefine tourism both as a subject and a tool. The first objective is to understand the position of tourism in the scientific development process. The second objective that derives from the first is to apply the epistemological reading to the study of French town and country planning developments stemming from the changes in the tourist industry.

\section{Methodology}

The first theoretical part of our research mobilised some 600 bibliographic references including significant books, articles and doctoral dissertations worldwide in order to retrace knowledge development in the core areas of tourism research - economics, history, geography, and sociology. In each of these fields, the main lines of research along with the initial comments, theorisations, and conceptual basis, were identified, listed, prioritized and analysed. The second part of our work had only one source of factual information: the daily national press. Two daily French papers - Le Monde and Les Échos - were read over a couple of years (2014/2015), in addition to occasional reading of Marianne, Challenges, Le Figaro Économie, Libération, and some fifty articles relating to tourism news were analysed with principal component and factor analysis methods.

\section{Theoretical conclusions}

Our research has shown that the $18^{\text {th }}$ century tourism revolution - alongside the industrial revolution - resonated in that of the $21^{\text {st }}$ century born with the digital changeover because the analysis of the economist Joseph Schumpeter (1883-1950) can be transferred there. Indeed the current digital upheaval corresponds to a new creative destruction with the introduction of innovative 
clusters. This forward momentum is quantitative - the number of international tourists quadrupled between 1980 and 2014, and increased by 44 since 1950 - and qualitative. In the $18^{\text {th }}$ century, Northern Europe, and more specifically Great Britain, introduced the tourist flow. Nowadays, the South does. The first tourist revolution matrix was the British aristocracy. The second tourist revolution is based on the rise in power of the upper middle class linked to international tourism assessed between 700 million and 1 billion people. Related to the development of a global upper middle class, the main source of tourists, now representing over $15 \%$ of the world's population, the land use plan mainly based on traditional domestic clientele, hence a rather steady stream of income segment, has to switch to upmarket urban tourism.

So, the evolution of tourism is marked by an innovative trend of the destinations, not following a development planning coming out of political bodies. The future is turning towards urban units. Tourism planning is no longer conditioned by secondary resorts in competition with each other, but by large urban units able to polarise distinct areas, that is to say to form ultimately new tourist development lines from a cutting-edge industry and a high class clientele.

\section{Practical application of the dissertation}

This report is aimed at French tourismplanning decision-makers. Two lines of thought are suggested relating to the impetus and the role of tourist resorts on the one hand and the impact of the hotel and interrelated catering sector on the other. Tourism development based on digital technology has extended the scope of the tourist industry. These changes, together with the move upmarket and the widening of the range of accommodation - whether in hotels or not has played a part in the diversification of the sector, confirming the necessity of redefining tourism. Tourism globalisation set up on upmarket structures does not challenge the trend known as 'mass tourism' but deprives it of any future prospects. Planning choices, even if they certainly depend on formal (such as the size of the towns concerned, the nature of the territory) and cyclical elements (the type of tourism developed, often inherited from a previous era), cannot ignore these new data.

\section{Content of the dissertation}

Our essay on redefining tourism is divided into two. The first part tackles tourism as a study topic and guides an exploratory reading on the emergence and deployment process as well as the nature and structure of scientific reflection in tourism - in other words, epistemology - an approach organised in four chapters. Chapters I and II retrace the birth of the tourist occurrence as an experience subject matter and its development as a knowledge object. Chapters III and IV analyse the origins of the construction of the scientific knowledge of tourism. In the second half, tourism is considered as an industry sector and its development and planning is dealt with. Chapter $V$ details a reflection on the basis for tourism planning in France. Chapter VI aims to redefine the tourist industry while Chapter VII presents a study of the tourist resort. Each aspect of this dual orientation seems to correspond to a creative destruction stage: the industrial revolution as well as the digital revolution. One finds its source at the end of the lengthy Middle Ages as defined by Jacques Le Goff, namely in the $18^{\text {th }}$ century. The other time-line takes shape in the early 1990s, following the Cold War, with the onset of globalism, i.e. the globalisation of capitalism.

\section{Abstract of chapter one}

The first chapter identifies tourism by locating the bringing in of its specific features in, correlatively, the travelling experience $\left(18^{\text {th }}\right.$ century), the English language (New English Dictionary on Historical Principles, 1780), then French (Boiste, 1828), the travel narrative typologies (19 $9^{\text {th }}$ century), and scientific research - hydrological from the $18^{\text {th }}$ century, then economic and historic in the final decades of the $19^{\text {th }}$ century. Economic research was marked by two currents of thought - entrepreneurial (Guyer, 1874) and theoretical (Stradner, 1884) - converging to the doctrine of tourism (Hunziker and Krapf, 
1942). It also provided the first scientific definition of tourism (Guyer, 1905), helped to find its greater idiosyncrasies - mobility between outbound and inbound locations, and relationship between hosts and guests and brought to light non-economic vectors. European historical research focused on travel in the $17^{\text {th }}, 18^{\text {th }}$ and $19^{\text {th }}$ centuries, the spa resorts development and Alps exploration. The North American perspective moved towards the study of leisure and national parks. The geographic research, still in a rather embryonic state, located tourist mobility in a spatial framework and their specific interrelation. The social research was in close contact with what will become its new object through the study of the stranger, while the sociology of tourism was foreshadowed (Franz Oppenheimer, 1932).

\section{Abstract of chapter two}

The second chapter provides the basis for identification in an expanded context of the onset of the building up of tourism as a scientific object, from which an economic paradigm emerged in Germany. Research in economics began in the 1870 s and asserted their primacy for a century, setting up hegemony in tourism knowledge and main lines with far-reaching consequences, including a late scientific interest in the tourism aspects outside economic issues and a consensual lack of interest for extensive operations. After World War II, the new research structure was organized in terms of internationalization, specialization and systematization. In the late 1970s, tourism research was organized in specific spheres, less dependent on scientific processes intended to other themes, but still governed by existing sciences concepts.

\section{Abstract of chapter three}

The third chapter deals with the framework of research that, from the 1950s, took a number of forms in terms of internationalisation, specialisation and systematisation. Its emergence comes definitely alive in the second half of the 1970s, conveyed by the substantial growth of journals, doctorate dissertations on the subject of tourism and by the forced-entry of social sciences interest in this field of investigation. Between the 1950s and 1960 s, carried by economically dominant line, tourism was perceived as a progressive force, but in the 1970s the debate centred on the developing interdisciplinary approach led by socio-anthropology made the pendulum swing back, and tourism was then regarded as a threat in terms of both socio-culture and economics.

\section{Abstract of chapter four \\ The fourth chapter studies intra-disciplinary tropisms. At the end of the 1970s research into tourism seemed to be constituted of specific spheres less dependent on attributed science inputs in favour of other subjects - but still subordinate to concepts of existing sciences. Once such things were examined in terms of science, it was quite unequal depending on the field. A parallel can be drawn up between the evolution of research in the disciplinary matrix concerned and the evolution of research into tourism. Thus as tourism macro-economy was being defined, it rapidly became powerful in the analysis of international tourism flows, whereas business economics struggled to theorise before expanding to marketing and management.}

\section{Abstract of chapter five}

The fifth chapter sets out the forms and principles of French local planning, then moves on to the processes of tourism planning in the different areas concerned rural, mountain and coastal. The sectors, players, evaluations and meanings of tourism are then reassessed. Our proposal for the redefinition makes a distinction between national and international tourism. It seemed to us that criteria differentiation is essential. Shared by both types of tourism: mobility and a daily spending of at least $50 \%$ on tourist products. Specific to international tourism: market sectors - such as perfumes and cosmetics, jewellery, haute-couture or high-end ready-to-wear clothes, wines and spirits, arts and crafts, including shopping tourism.

\section{Abstract of chapter six \\ Chapter six sheds light on the twofold challenge of the industry - digital and}


environmental - also relating back to its redefinition. The first is structural as the tourist industry is characterised by innovation. The creation and organisation of remote payment transactions for reservations is just one example. This was preceded at the end of the $19^{\text {th }}$ century by the invention of circular notes and travellers' cheques designed respectively by the tour operators, Thomas Cook and American Express. Furthermore the major sector of travel reservations, notably abroad, fostered internet companies. The industrial revolution of the $18^{\text {th }}$ and $19^{\text {th }}$ centuries contributed to the birth of international tourism. Its growth is strengthened by the digital revolution. However the increasing number of tourist trips throughout the world accentuates the environmental deterioration, due to the high concentration of infrastructures, populations and activities, especially on the coasts and in the major cities.

\section{Abstract of chapter seven}

The seventh and last chapter analyses the principal tool for tourist planning: the resort, dealt with from its origin to its current state and possible deadlocks. The elaboration of the concept of the tourist resort in Bath (South West England) at the very beginning of the $18^{\text {th }}$ century is studied. A typology of resorts is then given. Specialised or isolated - or both according to a unipolar (mono-activity) or multipolar (pluriactivity) operating choice, three historical types of resorts are observed: aristocratic resorts, dormitory resorts and new resorts. The tourist metropolises are not resorts but have tourist quarters. They give an impetus to urban tourism, mainly for culture and business, and boost tourist activity throughout the territory, its influence reaching geographically the whole country. They provide the direction, and by a leverage effect a different dimension to tourism. For a long time resorts located in hardly urbanised areas were considered as the only ones suitable for tourist development. With an upmarket international clientele questing for urban culture, the tourist industry asserts the identity of territories by enhancing their heritage value and ratifying the advent of globalism.

\section{References:}

Boiste, P. (1828). Dictionnaire universel de la langue française avec le latin et les étymologies. Bruxelles: Frechet libraire-éditeur.

Guyer-Freuler, E. (1874). Das Hotelwesen der Gegenwart. Orell, Füssli \& Company.

Guyer-Freuler, E. (1905). Fremdenverkehr und Hotelwesen. Bern, Suisse.

Hunziker, W., K. Krapf. (1942). Grundriss der Allgemeinen Fremdenverkehrslehre. $\mathrm{Nr} 1$ der Schriftenreihe des Seminars für Fremdenverkehr an der HandelsHochschule. St Gallen, Zurich.

Muňoz de Escalona, F. (1991). Critica de la economia turistica enfoque de offerta versus enfoque de demanda. Thèse d'économie. Madrid.

Murray, J. (1888).A New English Dictionary on Historical Principles. Oxford: Clarendon Press. 